\title{
CSF chitinase 3-like-1 association with disability of primary progressive MS
}

Francisco Pérez-Miralles, MD, PhD, Daniel Prefasi, MD, PhD, Antonio García-Merino, MD, PhD, Francisco Gascón-Giménez, MD, Nicolás Medrano, MD, Jessica Castillo-Villalba, MD, Laura Cubas, MD, Carmen Alcalá, MD, PhD, Sara Gil-Perotín, MD, Rocío Gómez-Ballesteros, BSci, MBA, Jorge Maurino, MD, Esther Álvarez-García, DVM, PhD, and Bonaventura Casanova, MD, PhD

Neurol Neuroimmunol Neuroinflamm 2020;7:e815. doi:10.1212/NXI.0000000000000815

\section{Abstract}

\section{Objective}

To assess the role of CSF chitinase 3-like-1 (CHI3L1), chitinase 3-like-2 (CHI3L2), and neurofilament light chain (NfL) in predicting the course of primary progressive MS (PPMS).

\section{Methods}

We analyzed CSF CHI3L1, CHI3L2, and NfL levels in 25 patients with PPMS with disease duration $\leq 10$ years and no disease-modifying therapy for $\geq 6$ months from the prospective Understanding Primary Progressive Multiple Sclerosis cohort study. CSF samples taken at disease diagnosis were analyzed using commercial ELISAs and following the manufacturer's instructions. Data on Expanded Disability Status Scale (EDSS) scores, disability progression, and cognitive function according to the Brief Repeatable Neuropsychological Battery were also assessed throughout the 1-year study follow-up.

\section{Results}

Increasing CHI3L1 levels correlated with higher EDSS scores at baseline $(\rho=0.490,95 \%$ CI $0.118-0.742, p=0.013)$ and month $12(\rho=0.455,95 \%$ CI $0.063-0.725, p=0.026)$ and tended to be associated with a higher risk of disability progression according to EDSS scores (OR = $1.008,95 \%$ CI $0.999-1.017, p=0.089$ ). Increasing CHI3L2 levels also tended to correlate with lower baseline EDSS scores $(\rho=-0.366,95 \%$ CI $-0.676-0.054, p=0.086)$. There was no correlation with regard to NfL levels.

\section{Conclusions}

This analysis supports the association between CSF CHI3L1 levels and neurologic disability according to EDSS scores in patients with PPMS. Other chitinase-like proteins such as CHI3L2 may also be involved.

\section{Classification of evidence}

This study provides Class II evidence that CSF CHI3L1 is associated with neurologic disability in patients with PPMS.
Correspondence

Dr. Pérez-Miralles

fcomiralles@comv.es

\section{MORE ONLINE}

$\rightarrow$ Class of Evidence

Criteria for rating

therapeutic and diagnostic studies

NPub.org/coe 


\section{Glossary}

9-HPT = 9-Hole Peg Test; CHI3L1 = chitinase 3-like-1; CHI3L2 = chitinase 3-like-2; CIS = clinically isolated syndrome; EDSS = Expanded Disability Status Scale; NfL = neurofilament light chain; PPMS = primary progressive MS; T25-fw = Timed 25-Foot Walk; UPPMS = Understanding Primary Progressive Multiple Sclerosis.

Several studies have explored CSF biomarkers reflecting inflammatory and neurodegenerative processes underlying MS, suggesting the prognostic role of chitinase 3-like-1 (CHI3L1), chitinase 3-like-2 (CHI3L2), and neurofilament light chain (NfL) in conversion to definite MS. ${ }^{1-4}$ Reported data have also pointed at measuring $\mathrm{CHI} 3 \mathrm{~L} 1$ and NfL to anticipate conversion to progressive disease, ${ }^{5}$ as well as supporting the biomarker use of CHI3L1 to monitor disease activity in secondary progressive $\mathrm{MS}^{6}$ and response to interferon-beta in relapsingremitting patients. ${ }^{7}$ These proteins may also be involved in the pathogenesis of the different MS forms, with a progressive increase in CHI3L1 levels with disease stages from clinically isolated syndrome (CIS), and an opposite variation of CHI3L2 expression in relapsing-remitting and progressive forms. ${ }^{1}$ However, they have not been fully characterized in patients with primary progressive MS (PPMS), and their role as predictive biomarkers of disease course remains unknown.

Therefore, we approached the analysis of CSF CHI3L1, CHI3L2, and NfL levels to assess their role in predicting disease course in patients with PPMS.

\section{Methods}

\section{Study design and participants}

This pilot CSF analysis included a sample of patients with PPMS from the prospective Understanding Primary Progressive Multiple Sclerosis (UPPMS) cohort study and provides Class II evidence.

Patients were consecutively recruited from neurologic departments at 11 Spanish hospitals between January and July 2017. Key eligibility criteria included age $\geq 18$ years, PPMS diagnosis according to the $2010 \mathrm{McDonald}$ criteria, ${ }^{8}$ disease duration $\leq 10$ years from neurologic symptom onset, and no disease-modifying therapy within the past 6 months.

\section{Assessments}

When CSF samples taken at MS diagnosis were available, an aliquot was sent to the Laboratory of Neuroimmunology "Dr. Francisco Coret"-Institut d'Investigació Sanitària La Fe (Valencia, Spain). Commercially available ELISAs for CHI3L1 (Quantikine ELISA kit, R\&D Systems Inc., Minneapolis), CHI3L2 (Human CHI3L2 ELISA kit, Cusabio Technology LLC, Houston), and NfL (NF-light neurofilament ELISA kit, UmanDiagnostics AB, Umea, Sweden) were used according to the manufacturer's instructions. Mean intra-assay variations were $6 \%, 8.9 \%$, and $1.7 \%$ for CHI3L1, $\mathrm{CHI} 3 \mathrm{~L} 2$, and NfL, respectively; all interassay variation coefficients were $<15 \%$.
Data on Expanded Disability Status Scale (EDSS) scores, disability progression, and cognitive function were collected throughout the 1-year study follow-up. Disability progression was assessed and confirmed $\geq 3$ months later according to the EDSS score ( $\geq 1$-point increase when the baseline score was $\leq 5.0$ or $\geq 0.5$-point increase when the baseline score was $\geq 5.5$ ), Timed 25-Foot Walk (T25-fw; $\geq 20 \%$ increase from baseline), 9-Hole Peg Test (9-HPT; $\geq 20 \%$ increase from baseline), and a composite of previously mentioned variables. The Rao Brief Repeatable Neuropsychological Battery was used to assess cognitive function.

\section{Statistical analyses}

CHI3L1, CHI3L2, and NfL levels were correlated with EDSS scores at enrollment (baseline) and month 12 using Spearman rank correlations. Associations of these levels with 12month disability progression and cognitive assessments were analyzed using Spearman rank correlations and logistic regressions. Indeterminate/missing data were not considered in the analyses, which were performed by Dynamic Science S.L. (Madrid, Spain) with the Statistical Package for the Social Sciences (SPSS) version 22.0 (SPSS Inc, Chicago) and a significance level of 0.05 .

\section{Standard protocol approvals, registrations, and patient consents}

The study was conducted according to Good Pharmacoepidemiology Practices, the Declaration of Helsinki, and national regulations. The ethics committee of Hospital Universitario 12 de Octubre approved it, and all patients gave their written informed consent.

\section{Data availability}

All data are reported within the article and available anonymized by request from qualified investigators.

\section{Results}

Twenty-five of the 55 patients enrolled in the UPPMS study had CSF samples taken at disease diagnosis (table).

Increasing CHI3L1 levels correlated with higher EDSS scores at baseline (Spearman $\rho=0.490,95 \%$ CI 0.118-0.742, $p=0.013$ ) and month 12 (Spearman $\rho=0.455,95 \%$ CI $0.063-0.725, p=$ 0.026 ) (figure). Conversely, increasing CHI3L2 levels tended to correlate with lower baseline EDSS scores (Spearman $\rho=$ $-0.366,95 \% \mathrm{CI}-0.676$ to $0.054, p=0.086$ ) (figure). There was no significant Spearman rank correlation between NfL levels and EDSS scores at baseline or month 12 (figure). 
Table Patient characteristics $(\mathrm{N}=25)$

\begin{tabular}{|c|c|}
\hline Characteristic & Value \\
\hline \multicolumn{2}{|l|}{ Age (y), median (IQR) } \\
\hline At MS diagnosis & $52.7(50.6-58.7)$ \\
\hline At baseline & $56.3(53.1-61.9)$ \\
\hline \multicolumn{2}{|l|}{ Sex, $n(\%)$} \\
\hline Male & $13(52.0)$ \\
\hline Female & $12(48.0)$ \\
\hline \multicolumn{2}{|l|}{ EDSS score, median (IQR) } \\
\hline At MS diagnosis & $3.5(2.5-4.5)^{\mathrm{a}}$ \\
\hline At baseline & $4.0(3.8-6.0)$ \\
\hline At month 12 & $4.3(3.6-6.0)^{b}$ \\
\hline \multicolumn{2}{|l|}{$\begin{array}{l}\text { CSF samples taken at MS diagnosis, median } \\
\text { (IQR) }\end{array}$} \\
\hline CHI3L1 level (ng/mL) & $199.1(140.8-266.8)$ \\
\hline CHI3L2 level (ng/mL) & $48.0(24.6-64.2)^{\mathrm{a}}$ \\
\hline NfL level (pg/mL) & $470.7(314.5-601.8)^{b}$ \\
\hline Time since MS diagnosis (y), median (IQR) & $3.4(1.2-6.4)$ \\
\hline \multicolumn{2}{|c|}{ 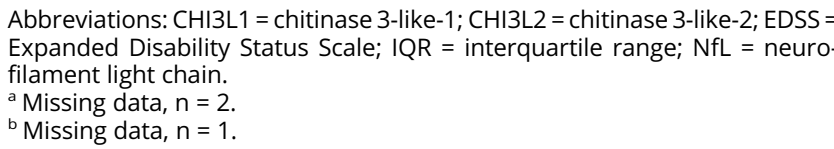 } \\
\hline
\end{tabular}

Three (12.0\%) patients experienced disability progression according to EDSS scores at month 12, 1 (4.0\%) according to T25-fw, none according to 9-HPT, and 4 (16.0\%) according to a composite of EDSS scores, T25-fw, or 9-HPT. Higher CHI3L1 levels tended to be associated with a higher risk of disability progression according to this composite $(\mathrm{OR}=$ $1.008,95 \%$ CI 0.999-1.018, $p=0.092$ ) and EDSS scores (OR $=1.008,95 \%$ CI $0.999-1.017, p=0.089)$, although there was no association regarding CHI3L2 (OR $=1.014,95 \% \mathrm{CI}$ $0.978-1.051, p=0.450)$ and NfL levels $(\mathrm{OR}=0.996,95 \% \mathrm{CI}$ $0.988-1.004, p=0.327$ ). There was no association with other disability progression measurements or cognitive assessments (data not shown).

\section{Discussion}

This pilot CSF analysis showed that CHI3L1 levels at PPMS diagnosis were related to EDSS scores at study follow-up. Higher CHI3L1 levels also tended to be associated with a higher risk of disability progression according to EDSS scores, although the relatively short study follow-up and the reduced sample size limited its power to detect significant differences. These results are in line with a previous report showing that CSF CHI3L1 correlated with EDSS scores through years 1-4 after the CIS episode. ${ }^{4}$ In addition, increasing CSF CHI3L1 expression was associated with a higher and earlier risk of developing a sustained EDSS score $\geq 3$ within 5 years after CIS. ${ }^{3}$ The CHI3L1 is a member of the glycoside hydrolase 18 chitinase family, whose increase throughout MS stages seems to derive from the extension of diffuse brain inflammation associated with neurologic impairment rather than acute inflammation during relapses ${ }^{1}$ and the detrimental role of astrocyte activation in disease pathogenesis. ${ }^{3}$

In addition, there was a trend toward finding lower CHI3L2 levels at disease diagnosis to be related with higher EDSS scores at study baseline and vice versa, suggesting a potential predictive role in PPMS that deserves further confirmation. CHI3L2 is another member of the glycoside hydrolase 18 chitinase family that was reported to predict MS development in patients with CIS. ${ }^{10}$ Contrasting to $\mathrm{CH} 3 \mathrm{~L} 1, \mathrm{CHI} 3 \mathrm{~L} 2$ levels are lower in progressive vs relapsing MS, which might result from their distinct temporal pattern of expression. ${ }^{1}$ However, we found no evidence on its role in predicting EDSS scores either in this patient population or in patients with PPMS.

Furthermore, our analyses provide no evidence to suggest the predictive value of NfL in patients with PPMS. As NfL is a cytoskeletal polypeptide of the axon whose release denotes axonal impairment, the lacking association may result from the underlying progressive neurodegenerative process rather than axonal damage outbreaks. ${ }^{5}$

We acknowledge that the analysis has limitations that may affect its statistical power, including the limited study followup, sample size, and patients with disability progression. However, we identified significant differences and tendencies deserving confirmation. Despite the absence of significant differences or tendencies according to NfL levels, additional data on larger sample sizes, longer follow-ups, and using SIMOA technology, preferably in serum, are needed to confirm its role in patients with PPMS. In addition, the observational, prospective, and multicenter nature of the study supports the generalizability of analysis findings to clinical practice.

This analysis supports the association between CSF CHI3L1 levels and neurologic disability according to EDSS scores in patients with PPMS. Other chitinase-like proteins such as CHI3L2 may also be involved. These findings warrant further confirmatory assessment in larger samples of patients with PPMS.

\section{Acknowledgment}

The authors are extremely grateful to all the patients and their families for making the UPPMS study possible. Medical writing support was provided by Esther Álvarez-García (Dynamic Science S.L.) during the preparation of this article (funded by Roche Farma S.A), who contributed to drafting, editing, and word processing the manuscript as well as responding to the editor and reviewers' comments. 

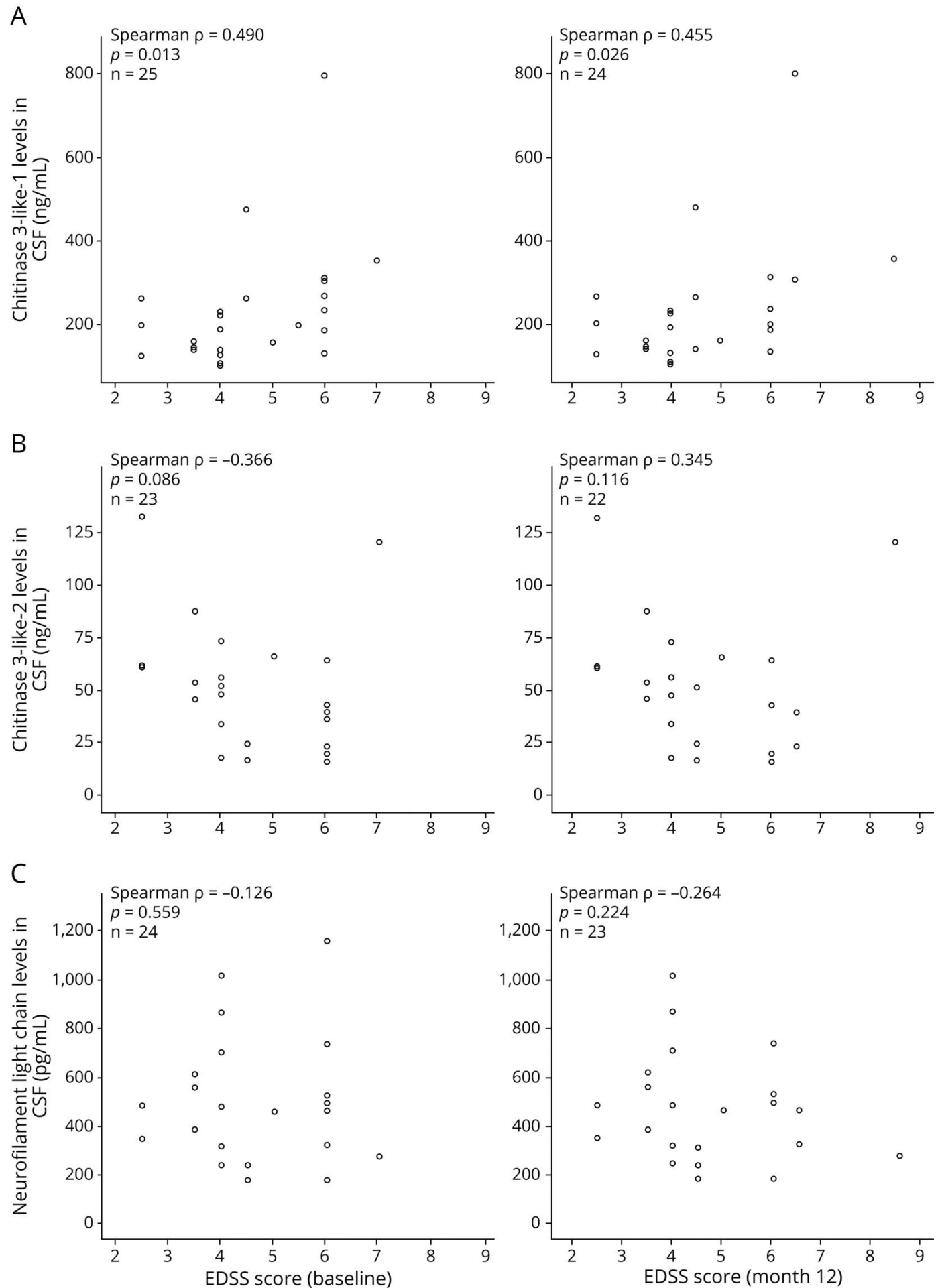

This figure shows the results of the Spearman rank correlations of chitinase 3-like-1 (A), chitinase 3-like-2 (B), and neurofilament light chain (C) levels with Expanded Disability Status Scale scores.

\section{Study funding}

The authors disclosed receipt of the following financial support for the research, authorship, and publication of this article: This work was supported by Roche Farma S.A. (ML39253).

\section{Disclosure}

F. Pérez-Miralles was part of the steering committee of the UPPMS study and has received compensation for serving on scientific advisory boards or speaking honoraria from Almirall, Biogen Idec, Genzyme, Merck Serono, Mylan, Novartis, Roche, 
Sanofi-Aventis, and Teva, outside the submitted work. D. Prefasi is an employee of Roche Farma S.A. A. García-Merino has received consultant and/or lecture fees from Merck, Teva, Biogen, Novartis, Roche, and Sanofi. F. Gascón-Giménez reports no disclosures. N. Medrano is an employee of Roche Farma S.A. J. Castillo-Villalba, L. Cubas, C. Alcalá, and S. Gil-Perotín report no disclosures. R. Gómez-Ballesteros and J. Maurino are employees of Roche Farma S.A. E. Álvarez-García is an employee of Dynamic Science S.L. B. Casanova reports no disclosures. Go to Neurology.org/NN for full disclosures.

\section{Publication history}

Received by Neurology: Neuroimmunology \& Neuroinflammation January 29, 2020. Accepted in final form May 1, 2020.

Appendix Authors

\begin{tabular}{|c|c|c|}
\hline Name & Location & Contribution \\
\hline $\begin{array}{l}\text { Francisco } \\
\text { Pérez- } \\
\text { Miralles, MD, } \\
\text { PhD }\end{array}$ & $\begin{array}{l}\text { Hospital Universitari i } \\
\text { Politècnic La Fe, } \\
\text { Valencia, Spain }\end{array}$ & $\begin{array}{l}\text { Design and } \\
\text { conceptualization of the } \\
\text { study; major role in the } \\
\text { acquisition of data; analysis } \\
\text { and interpretation of the } \\
\text { data; and drafting and } \\
\text { revising the manuscript }\end{array}$ \\
\hline $\begin{array}{l}\text { Daniel Prefasi, } \\
\text { MD, PhD }\end{array}$ & $\begin{array}{l}\text { Roche Farma S.A., } \\
\text { Madrid, Spain }\end{array}$ & $\begin{array}{l}\text { Design and } \\
\text { conceptualization of the } \\
\text { study; analysis and } \\
\text { interpretation of the data; } \\
\text { and drafting and revising } \\
\text { the manuscript }\end{array}$ \\
\hline
\end{tabular}

\begin{tabular}{|c|c|c|}
\hline $\begin{array}{l}\text { Antonio } \\
\text { García- } \\
\text { Merino, MD, } \\
\text { PhD }\end{array}$ & $\begin{array}{l}\text { Hospital Universitario } \\
\text { Puerta de Hierro, } \\
\text { Madrid, Spain }\end{array}$ & $\begin{array}{l}\text { Design and } \\
\text { conceptualization of the } \\
\text { study; major role in the } \\
\text { acquisition of data; } \\
\text { analysis and interpretation } \\
\text { of the data; and drafting } \\
\text { and revising the } \\
\text { manuscript }\end{array}$ \\
\hline
\end{tabular}

\begin{tabular}{lll}
\hline Francisco & Hospital Clínico & Design and \\
Gascón- & Universitario de & conceptualization of the \\
Giménez, MD & Valencia, Valencia, & $\begin{array}{l}\text { study; major role in the } \\
\text { acquisition of data; analysis } \\
\text { Spain }\end{array}$ \\
& $\begin{array}{l}\text { and interpretation of the } \\
\text { data; and drafting and } \\
\text { revising the manuscript }\end{array}$
\end{tabular}

\begin{tabular}{lll}
\hline Nicolás & Roche Farma S.A., & Design and \\
Medrano, MD & Madrid, Spain & conceptualization of the
\end{tabular}
study; analysis and interpretation of the data; and drafting and revising the manuscript

\begin{tabular}{lll}
\hline $\begin{array}{l}\text { Jessica } \\
\text { Castillo- } \\
\text { Villalba, MD }\end{array}$ & $\begin{array}{l}\text { Instituto de } \\
\text { Investigación Sanitaria } \\
\text { La Fe, Valencia, Spain }\end{array}$ & $\begin{array}{l}\text { Design and } \\
\text { conceptualization of the } \\
\text { study; major role in the } \\
\text { acquisition of data; analysis } \\
\text { and interpretation of the } \\
\text { data; and drafting and } \\
\text { revising the manuscript }\end{array}$ \\
\hline $\begin{array}{ll}\text { Laura Cubas, } \\
\text { MD }\end{array}$ & $\begin{array}{l}\text { Instituto de } \\
\text { Investigación Sanitaria } \\
\text { La Fe, Valencia, Spain }\end{array}$ & $\begin{array}{l}\text { Design and } \\
\text { conceptualization of the } \\
\text { study; major role in the } \\
\text { acquisition of data; analysis } \\
\text { and interpretation of the } \\
\text { data; and drafting and } \\
\text { revising the manuscript }\end{array}$ \\
& &
\end{tabular}

Appendix (continued)

\begin{tabular}{|c|c|c|}
\hline Name & Location & Contribution \\
\hline $\begin{array}{l}\text { Carmen } \\
\text { Alcalá, MD, } \\
\text { PhD }\end{array}$ & $\begin{array}{l}\text { Hospital Universitari i } \\
\text { Politècnic La Fe, } \\
\text { Valencia, Spain }\end{array}$ & $\begin{array}{l}\text { Design and } \\
\text { conceptualization of the } \\
\text { study; major role in the } \\
\text { acquisition of data; analysis } \\
\text { and interpretation of the } \\
\text { data; and drafting and } \\
\text { revising the manuscript }\end{array}$ \\
\hline $\begin{array}{l}\text { Sara Gil- } \\
\text { Perotín, MD }\end{array}$ & $\begin{array}{l}\text { Instituto de } \\
\text { Investigación Sanitaria } \\
\text { La Fe, Valencia, Spain }\end{array}$ & $\begin{array}{l}\text { Design and } \\
\text { conceptualization of the } \\
\text { study; major role in the } \\
\text { acquisition of data; analysis } \\
\text { and interpretation of the } \\
\text { data; and drafting and } \\
\text { revising the manuscript }\end{array}$ \\
\hline $\begin{array}{l}\text { Rocío Gómez- } \\
\text { Ballesteros, } \\
\text { BSci, MBA }\end{array}$ & $\begin{array}{l}\text { Roche Farma S.A., } \\
\text { Madrid, Spain }\end{array}$ & $\begin{array}{l}\text { Design and } \\
\text { conceptualization of the } \\
\text { study; analysis and } \\
\text { interpretation of the data; } \\
\text { and drafting and revising } \\
\text { the manuscript }\end{array}$ \\
\hline $\begin{array}{l}\text { Jorge Maurino, } \\
\text { MD }\end{array}$ & $\begin{array}{l}\text { Roche Farma S.A., } \\
\text { Madrid, Spain }\end{array}$ & $\begin{array}{l}\text { Design and } \\
\text { conceptualization of the } \\
\text { study; analysis and } \\
\text { interpretation of the data; } \\
\text { and drafting and revising } \\
\text { the manuscript }\end{array}$ \\
\hline $\begin{array}{l}\text { Esther } \\
\text { Álvarez- } \\
\text { García, DVM, } \\
\text { PhD }\end{array}$ & Dynamic Science S.L. & $\begin{array}{l}\text { Drafting and revising the } \\
\text { manuscript; responding to } \\
\text { the reviewer comments; } \\
\text { technical editing; } \\
\text { copyediting; and word } \\
\text { processing }\end{array}$ \\
\hline $\begin{array}{l}\text { Bonaventura } \\
\text { Casanova, MD, } \\
\text { PhD }\end{array}$ & $\begin{array}{l}\text { Hospital Universitari i } \\
\text { Politècnic La Fe, } \\
\text { Valencia, Spain }\end{array}$ & $\begin{array}{l}\text { Design and } \\
\text { conceptualization of the } \\
\text { study; major role in the } \\
\text { acquisition of data; } \\
\text { analysis and interpretation } \\
\text { of the data; and drafting } \\
\text { and revising the } \\
\text { 4manuscript }\end{array}$ \\
\hline
\end{tabular}

\section{References}

1. Hinsinger G, Galeotti N, Nabholz N, et al. Chitinase 3-like proteins as diagnostic and prognostic biomarkers of multiple sclerosis. Mult Scler 2015;21:1251-1261.

2. Arrambide G, Espejo C, Eixarch H, et al. Neurofilament light chain level is a weak risk factor for the development of MS. Neurology 2016;87:1076-1084.

3. Canto E, Tintore M, Villar LM, et al. Chitinase 3-like 1: prognostic biomarker in clinically isolated syndromes. Brain 2015;138:918-931.

4. Comabella M, Fernandez M, Martin R, et al. Cerebrospinal fluid chitinase 3-like 1 levels are associated with conversion to multiple sclerosis. Brain 2010;133: 1082-1093.

5. Gil-Perotin S, Castillo-Villalba J, Cubas-Nunez L, et al. Combined cerebrospinal fluid neurofilament light chain protein and chitinase-3 like-1 levels in defining disease course and prognosis in multiple sclerosis. Front Neurol 2019;10:1008.

6. Burman J, Raininko R, Blennow K, Zetterberg H, Axelsson M, Malmestrom C. YKL40 is a CSF biomarker of intrathecal inflammation in secondary progressive multiple sclerosis. J Neuroimmunol 2016;292:52-57.

7. Matute-Blanch C, Rio J, Villar LM, et al. Chitinase 3-like 1 is associated with the response to interferon-beta treatment in multiple sclerosis. J Neuroimmunol 2017; 303:62-65.

8. Polman $\mathrm{CH}$, Reingold SC, Banwell B, et al. Diagnostic criteria for multiple sclerosis: 2010 revisions to the McDonald criteria. Ann Neurol 2011;69:292-302.

9. Boringa JB, Lazeron RH, Reuling IE, et al. The brief repeatable battery of neuropsychological tests: normative values allow application in multiple sclerosis clinical practice. Mult Scler 2001;7:263-267.

10. Mollgaard M, Degn M, Sellebjerg F, Frederiksen JL, Modvig S. Cerebrospinal fluid chitinase-3-like 2 and chitotriosidase are potential prognostic biomarkers in early multiple sclerosis. Eur J Neurol 2016;23:898-905. 


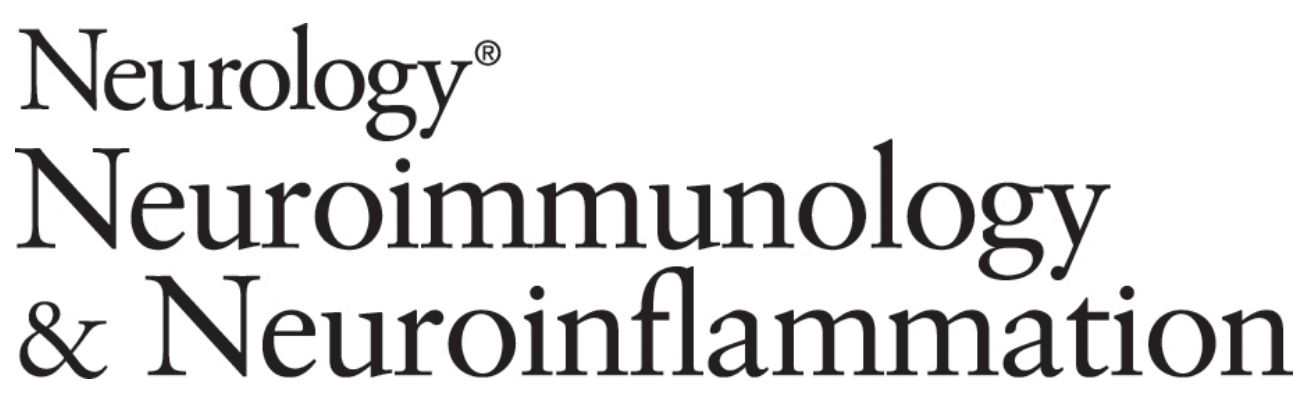

CSF chitinase 3-like-1 association with disability of primary progressive MS Francisco Pérez-Miralles, Daniel Prefasi, Antonio García-Merino, et al.

Neurol Neuroimmunol Neuroinflamm 2020;7;

DOI 10.1212/NXI.0000000000000815

This information is current as of July 1, 2020

Neurol Neuroimmunol Neuroinflamm is an official journal of the American Academy of Neurology.

Published since April 2014, it is an open-access, online-only, continuous publication journal. Copyright

Copyright $\odot 2020$ The Author(s). Published by Wolters Kluwer Health, Inc. on behalf of the American

Academy of Neurology.. All rights reserved. Online ISSN: 2332-7812.

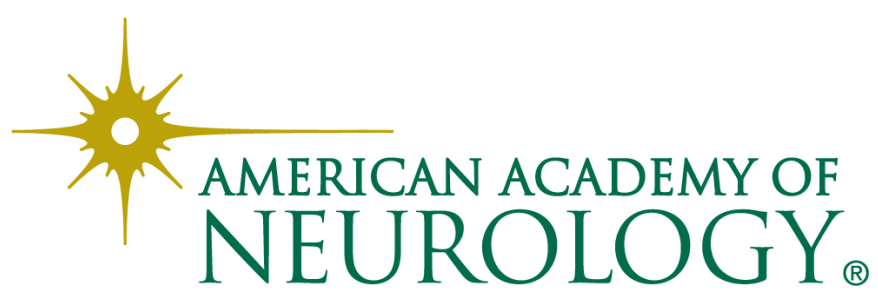




\section{Updated Information \& Services}

References

Citations

Subspecialty Collections

Permissions \& Licensing

Reprints including high resolution figures, can be found at: http://nn.neurology.org/content/7/5/e815.full.html

This article cites 10 articles, 0 of which you can access for free at: http://nn.neurology.org/content/7/5/e815.full.html\#\#ref-list-1

This article has been cited by 4 HighWire-hosted articles: http://nn.neurology.org/content/7/5/e815.full.html\#\#otherarticles

This article, along with others on similar topics, appears in the following collection(s):

Cerebrospinal Fluid

http://nn.neurology.org//cgi/collection/cerebrospinal_fluid Cohort studies

http://nn.neurology.org//cgi/collection/cohort_studies

Multiple sclerosis

http://nn.neurology.org//cgi/collection/multiple_sclerosis

Natural history studies (prognosis)

http://nn.neurology.org//cgi/collection/natural_history_studies_prognos is

Risk factors in epidemiology

http://nn.neurology.org//cgi/collection/risk_factors_in_epidemiology

Information about reproducing this article in parts (figures,tables) or in its entirety can be found online at:

http://nn.neurology.org/misc/about.xhtml\#permissions

Information about ordering reprints can be found online:

http://nn.neurology.org/misc/addir.xhtml\#reprintsus

Neurol Neuroimmunol Neuroinflamm is an official journal of the American Academy of Neurology.

Published since April 2014, it is an open-access, online-only, continuous publication journal. Copyright

Copyright $\odot 2020$ The Author(s). Published by Wolters Kluwer Health, Inc. on behalf of the American

Academy of Neurology.. All rights reserved. Online ISSN: 2332-7812.

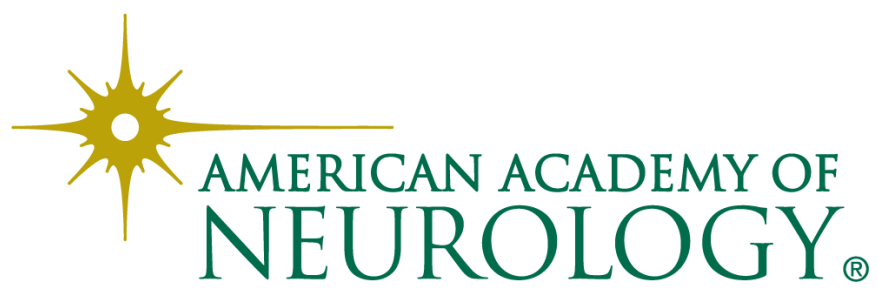

